\title{
Postawa męstwa bycia - odpowiedź dana nie tylko Hamletowi
}

\author{
Marcin Hintz iD https://orcid.org/0000-0001-7663-1085 \\ Chrześcijańska Akademia Teologiczna w Warszawie \\ e-mail:m.hintz@chat.edu.pl \\ Maria Urbańska-Bożek (iD https://orcid.org/0000-0003-0016-602X \\ Pomorskie Towarzystwo Filozoficzno-Teologiczne \\ e-mail: murbanska-bozek@swps.edu.pl
}

\section{Abstract \\ Attitude of the Courage to Be - Response Given Not Only to Hamlet}

The article comprises an analysis of the concept of "courage" as an ontological and ethical principle, constituting the chief category in the philosophical theology of Paul Tillich, called "the philosopher of borderlands," regarded as the most important thinker in the Protestant, liberal theology of the 20th century. In his philosophical theology or theological philosophy the notion of "courage to be" provides an essential point of reference in the context of spiritual development of the human individual, as well as revealing possibilities of giving sense to being, which appears itself to man as devoid of sense. In the first part, the concept of "courage to be" is itself subjected to analysis as the ontological and the ethical principle. According to Tillich, the existentially (ethically) oriented being constituted a step in the individual's life, which is already connected with conscious life and self-affirmation. The second part discusses Tillich's understanding of faith as the "to be or not to be" of human existence. The author of Dynamics of Faith says that the courage to be can be expressed either in individuation, that is, in the personal relationship and encounter with God, which represents the existentialist approach, or by means of participation in God's power. Tillich proclaims that only the virtue of courage can overcome the anxiety arising from lack of sense and from doubt, which is characteristic of human life.

Keywords: courage, existence, Paul Tillich, faith, ontological principle, ethical principle, despair, anxiety

Słowa kluczowe: męstwo, egzystencja, Paul Tillich, wiara, zasada ontologiczna, zasada etyczna, rozpacz, lęk 


\section{„Męstwo bycia” jako zasada ontyczna i etyczna}

W Bojaźni i drżeniu Søren Kierkegaard wspomina o rycerzach wiary oraz „nieskończonej rezygnacji”. Do pierwszej z wymienionych kategorii zaliczał między innymi Abrahama, Marię - matka Jezusa, Sarę - żona Tobiasza, a także męczenników. Do grupy „rycerzy rezygnacji” włączał Sokratesa, Agamemnona, Jeftego oraz, w skrytości ducha, siebie samego ${ }^{1}$. Paul Tillich, analogicznie, przypisuje męstwo bycia rycerzom bycia, uznającym swą rozumną naturę wbrew temu, co odnajdują w sobie jako przygodne, skończone, śmiertelne ${ }^{2}$. Myśliciel nauczył się od Martina Heideggera, że życie to nieustanne dążenie ku śmierci. Lęk przed śmiercią jest egzystencjalnym doświadczeniem. Niemniej, zdaniem teologa, strach ten może zostać przezwyciężony dzięki odniesieniu się do „rozumu powszechnego” - Boga, który, działając w naszym centrum osobowym i poprzez nie, jest w stanie urzeczywistnić męstwo istniejące w nas jako możliwość ${ }^{3}$.

Tillich opisuje lęk jako „egzystencjalną świadomość niebytu”, dotykającą trzech sfer: istnienia (ontycznej), ducha i moralności. Lęk, w przeciwieństwie do strachu, nie posiada swojego przedmiotu. Czujemy lęk przed nie-byciem, a strach przed śmiercią, agonią, odrzuceniem. Pierwszy lęk powstaje w wyniku zagrożenia ze strony nie-bytu i dotyczy pozbawienia istnienia. Jest on odczuwany w sposób bezwzględny jako śmierć, w sposób względny jako los. Tym, co dla losu jest charakterystyczne, jest przygodność, sprawiająca, że jawi się on jako możliwość, która może, lecz nie musi zaistniećt .

Drugi lęk wiąże się z niebytem „duchowej afirmacji człowieka”, bezwzględnie identyfikowanym jako bezsens, względnie jako pustka. Człowiek dopiero wówczas może mówić o duchowej afirmacji, gdy twórczo uczestniczy w życiu, co nie oznacza bycia twórcą sensu stricto, lecz umiejętność używania i korzystania z tego, co oferują nauka oraz kultura. Jednostka pozbawiona tej możliwości narażona jest na duchową pustkę lub uczucie braku sensu, co stanowi zagrożenie dla życia duchowego. Wtedy pojawia się wątpienie, które w wymiarze totalnym powoduje, iż przyjęty do tej pory system wartości upada lub dezaktualizuje się, ponieważ dotychczas posiadane przekonania nie przemawiają już do rozumu ludzkiego, są niezrozumiałe w konfrontacji z nową sytuacją, czasem oraz przemianami kulturowo-społecznymi etc. ${ }^{5}$

Trzeci lęk związany jest z zagrożeniem moralnej samoafirmacji człowieka. Przejawia się w sposób bezwzględny jako lęk przed potępieniem, a w sposób względny jako lęk przed winą, ujawniający się w sumieniu człowieka ${ }^{6}$.

Wszystkie trzy typy lęku wymienione przez Tillicha mają charakter egzystencjalny i w swej skrajnej formie przybierają postać rozpaczy - tego, co ostateczne

${ }^{1}$ Por. S. Kierkegaard, Bojaźń i drżenie, tłum. K. Toeplitz, wstęp J.A. Prokopski, red. nauk. M. Urbańska-Bożek, Kęty 2018, s. 113-153.

${ }^{2}$ Por. P. Tillich, Męstwo bycia, thum. H. Bednarek, Poznań 1994, s. 19.

3 Ibidem, s. 20-21.

${ }^{4}$ Ibidem, s. 58-52.

5 Por. ibidem, s. 52-57.

${ }^{6}$ Ibidem, s. 57-60. 
i ,graniczne”. Rozpacz pozbawia człowieka dalszych złudzeń dotyczących możliwości ocalenia siebie w sensie duchowym i fizycznym. Gdyby lęk odnosił się tylko do sfery losu i śmierci, akt samobójczy stanowiłby proste wyjście z pułapki rozpaczy ${ }^{7}$. Jednakże dla chrześcijanina nie stanowi on rozwiązania, ponieważ samowolne przerwanie ciągłości życia pociąga za sobą konsekwencje w postaci wiecznego potępienia.

Jako przeciwwagę dla nie-bycia, które nieustannie zagraża byciu człowieka, Tillich proponuje użyć cnoty męstwa, pojmowanej nie tylko jako zasada etyczna, lecz również ontologiczna. Przy jej pomocy jednostka ludzka jest w stanie podjąć walkę z lękiem, co stanowi wyraz doskonałej witalności lub siły życiowej. Największy przejaw tej witalności autor Męstwa bycia widzi w technice. Podobnie w języku upatruje on dowodu panowania człowieka nad światem zwierząt. Tillich, formułując koncepcję męstwa, przywołuje starożytny termin areté, łączący „siłę i wartość, moc bycia i osiąniecie pełni znaczenia" ". Człowiek homerycki ${ }^{10}$ mierzył swą areté miarą uznania, którym cieszył się między równymi sobie. Natomiast Platon, podobnie jak Stagiryta, widzieli pełnię areté w duchowej postawie człowieka świadomego swej wartości. Również Tillich był zdania, że „nic innego jak tylko duchowo ukształtowana witalność czyni człowieka areté"11, samo zaś męstwo powinno zostać oparte na samoafirmacji bytu ${ }^{12}$.

Męstwo jako pojęcie ontologiczne jest ,,powszechną i istotną afirmacją danego bytu”" ${ }^{13}$. Z kolei na gruncie etyki męstwo to ,akt etyczny, w którym człowiek afirmuje własny byt wbrew tym elementom swego istnienia, które przeciwstawiają się podstawowej afirmacji człowieka"14. Pytając o podstawę źródła męstwa bycia jako zasady ontologicznej, Tillich odsyła nas do Mocy Bytu, dzięki której jednostka może afirmować samą siebie ${ }^{15}$. O tej ontologicznej samoafirmacji filozof mówi, że jest

7 Ibidem, s. 61.

${ }^{8}$ Ibidem, s. 88. Tillich odróżnia lęk egzystencjalny od lęku patologicznego, na przykład neurozy. Różnica między osobą neurotyczną a zdrową (choć potencjalnie neurotyczną) sprowadza się do tego, że „pierwsza wskutek swej większej wrażliwości na niebyt i, co za tym idzie, swego głębszego lęku znajduje stabilizację w pewnym rodzaju stałej, choć ograniczonej i nie liczącej się z rzeczywistością, samoafirmacji”. Samoafirmacja dla osoby neurotycznej jest czymś na kształt twierdzy, do której wycofuje się i chowa, aby ocalić resztki samego siebie. Posunięcie to chroni ją przed totalną rozpaczą. Ibidem, s. 77.

9 Ibidem, s. 91.

${ }^{10}$ Człowiek, który odniesienie/wzór dla swych zalet i wad odnajdywał w bohaterach poematów Homera. Szerzej na ten temat zob. J. Parandowski, Człowiek homerycki, „Roczniki Filozoficzne” 1949/1950, t. 2/3, s. 199-204.

11 Werner Jaeger, w słynnej pracy zatytułowanej Paideia, wykazuje, że u Homera areté jest przymiotem, czymś w rodzaju szlachectwa, przysługującego tylko ludziom wysoko urodzonym. Por. W. Jaeger, Paideia, t. 1, tłum. M. Plezia, Warszawa 1962, s. 35-46.

12 B. Milerski, Religia a Słowo. Krytyka religii w ujęciu Dietricha Bonhoeffera i Paula Tillicha, Łódź 1994, s. 162.

13 P. Tillich, Męstwo bycia, op. cit., s. 8-9.

14 Ibidem.

15 W ten sposób sam Bóg przekracza swoje granice, staje się Bogiem ponad wyobrażeniem tradycyjnego teizmu, por. M. Napadło, Pytanie o Boga... Filozofia religii Paula Tillicha, Płock 2015, s. 185 i n. Tillichowskie zrozumienie nowotestamentowego pistis (,wiara”) zdecydowanie przekracza granice zakreślone przez szesnastowieczne reformacyjne rozumienie tego pojęcia, por. H. Theißen, Der gemeinsame reformatorische Grund des Glaubens, ,Gdański Rocznik Ewangelicki” 2013, vol. 7, s. 311. 
obojętna pod względem wartościowania, a nawet przekracza wszelkie skale wartościowania ${ }^{16}$. Separowanie własnego ,ja”, zapewnia niemiecki teolog, nie jest wyobcowaniem, tak jak skupienie się na sobie nie jest samolubstwem, a samookreślenie nie jest grzechem. Na poziomie czystego istnienia, czyli na poziomie ontologicznym działania natury rzeczy, czy też siły życiowej - nie ma możliwości samoafirmacji lub afirmacji ,ja” jako ,ja”, gdyż siła ta działa poza naszą świadomością, a samo „ja” jeszcze nie zostało ukształtowane. Chcąc zatem dobrze zrozumieć myśl Tillicha, warto wnikliwiej przeanalizować tezę stanowiącą, że ontologiczna samoafirmacja jest obojętna pod względem wartościowania.

Istnieje w jednostce ludzkiej siła, która przejawia się jako męstwo afirmujące istnienie osoby, niebędącej jednak w pełni ,ja" osobowym (u samoświadomego i w pełni ukształtowanego ,ja" istnienie jest zreflektowane i jawi się jako egzystencja). Tillich pisze, że „pojęcia charakteryzujące indywidualne «ja» znajdują się przed różnicującym wartościowaniem”. Samoafirmacja czy też afirmacja ,ja” sugeruje zwrócenie się ku sobie, skierowanie uwagi na siebie identyfikowanego jako ,ja”. Konstytuowanie się ,ja” odbywa się między innymi za pomocą różnicującego wartościowania”, w licznych odniesieniach i konfiguracjach międzybytowych (ja - świat, ja - inny, ja - Bóg). Jak zatem możliwa jest neutralność aksjologiczna? Odpowiedź jest następująca: „«ja» jako «ja»” jest czymś na kształt zindywidualizowanego przed-ja, które, mimo że nie jest świadome siebie, to afirmuje ,ja” jako należące do mnie, jako moje istnienie, które należy chronić i zachować jako najwyższe dobro. Do aktu tej afirmacji dochodzi poza świadomością, dlatego „poza różnicującym wartościowaniem”.

Gdybyśmy myśl Tillicha chcieli wyrazić w kategoriach metafizyki klasycznej (rozumianej po Arystotelesowsku jako teologia, czyli nauka o pierwszych przyczynach i zasadach), to afirmacja ,ja” byłaby możliwa nie za sprawą męstwa, lecz natury rzeczy (phisis) lub mocy podobnej do Bergsonowskiego élan vital ${ }^{17}$, która - ujęta jako jednostkowa istota rzeczy (gr. to ti en einai, łac. essentia) - stanowi o tożsamości bytu w jego konkretnym, zindywidualizowanym rozwoju czasowym. Ta jednostkowa istota rzeczy afirmuje konkretne ,ja”, chociaż ani Arystoteles, ani filozofowie średniowieczni nie definiowali jej w kategoriach męstwa, tak jak robi to Tillich, lecz jako wewnętrzną zasadę ruchu i spoczynku w bycie, a więc jako zasadę życia. Również inne byty, odmienne od człowieka i stojące z racji nieposiadania duszy rozumnej niżej w hierarchii stworzeń, obdarowane zostały tą samą zasadą życia/męstwa. „Męstwo bycia - pisze niemiecki teolog - we wszystkich swych postaciach ma samo przez się charakter odkrywczy"18, stanowiąc klucz do bytu jako bytu. Autor Dynamiki wiary jest przekonany, że byt zawiera w sobie nie-byt, lecz ten ostatni nie góruje nad nim. Samoafirmacja bez nie-bytu jako swego alter ego byłaby jedynie „statyczną tożsamością"19. Nie-byt zmusza byt, przez wzajemną negację i znoszenie się

${ }^{16}$ P. Tillich, Męstwo bycia, op. cit., s. 98.

${ }^{17}$ Tillich często odwołuje się w Męstwie bycia do twórczej siły, dzięki której możliwe stają się rozwój i życie. „W procesie boskiego życia” przezwyciężany jest niebyt, który z konieczności musi towarzyszyć bytowi, aby stawiał on opór temu pierwszemu. W ten oto sposób przejawia się twórcze istnienie. W tym twórczym procesie swoje źródło odnajduje również męstwo. Por. ibidem, s. 21.

18 Ibidem, s. 191.

${ }^{19}$ Ibidem. 
nawzajem, do ukazania swej wewnętrznej dynamiki. Za sprawą tego dialektycznego napięcia między bytem i nie-bytem możliwy jest ruch życia oraz sama pozytywność. Nie-byt z ontologicznego punktu widzenia jest czymś pozytywnym, twórczym, napędzającym spiralę życia w obrębie gatunku.

Bycie egzystencjalnie zorientowane stanowi kolejny krok, który jest już powiązany z życiem świadomym i samoafirmacją. W tej konfiguracji nie-byt nie jawi się jako pozytywność, lecz coś, co zagraża egzystencji. Uświadomiony nie-byt może prowadzić do rozpaczy, nie jest też obojętny aksjologicznie i etycznie. Zatem ontologiczna afirmacja bytu odbywa się poza świadomością człowieka, sprowadza się do instynktu, który „nie wiedząc wie”20. Natomiast „samoświadoma afirmacja” odbywa się w granicach egzystencji, myślenia o własnym byciu.

Tillich pragnął przy pomocy zasady męstwa, jako zarazem ontologicznej i etycznej, wyjaśnić wielowątkową i skomplikowaną strukturę bytu, jakim jest człowiek. Z płaszczyzny czystego istnienia odpowiedź na pytanie o ludzkie bycie pozostanie zawsze pozytywna i afirmatywna, a jednocześnie niejednoznaczna oraz złożona, gdy wejdziemy w obszar ludzkiej egzystencji.

\section{Wiara - „być albo nie być” ludzkiej egzystencji}

Pytanie o sens ludzkiego bycia zostało postawione na długo przed tym, zanim w postaci alternatywy wykluczającej - sformułował je William Szekspir. Jednak szczególnego znaczenia odpowiedź na nie nabrała po tragicznych wydarzeniach II wojny światowej.

Według Jeana Améry'ego, belgijskiego intelektualisty austriackiego pochodzenia, Żyda i więźnia Auschwitz, tam, gdzie przyszło mu spędzić kilka lat życia „,...] umysł jako całość ogłaszał swą niekompetencję"21, w obozie całkowicie kapitulował, nie spełniając swoich zadań. Rozum funkcji myślenia używał już tylko do autonegacji, ponieważ nieustannie natrafiał na nieprzekraczalne granice własnego myślenia: „Przy tej okazji pękały osie jego tradycyjnych systemów odniesienia. Piękno było tylko złudzeniem. Poznanie okazywało się igraniem pojęciami”"22. Sam człowiek nie jawił się już jako byt wyniesiony ponad świat zwierzęcy. Podobnie działo się w kwestii tak zwanych spraw ostatecznych, gdzie rozum porzucał tych, którzy na nim budowali własne życie. Jeśli człowiek nie opierał się na wierze w Boga lub jakiejś idei przewodniej (społecznej, politycznej), tracił rację swego bytu ${ }^{23}$. W obozach śmierci lęk przed potępieniem i grzechem oraz utrata sensu życia, będąca pokłosiem lęku przed śmiercią (który, jak się okazuje, w pewnych okolicznościach może zostać zniesiony przez jeszcze bardziej pierwotny, mianowicie przez lęk przed umieraniem), zatraciły swój egzystencjalny charakter, przestały być problemem, i, jako

\footnotetext{
${ }^{20}$ H. Bergson, Ewolucja twórcza, tłum. F. Znaniecki, wstęp L. Kołakowski, Kraków 2004, s. 153-161.

${ }^{21}$ J. Améry, Poza wina i kara. Próby przełamania podjęte przez złamanego, tłum. R. Turczyn, posłowiem opatrzył P. Weiser, Kraków 2007, s. 58.

${ }^{22}$ Ibidem.

${ }^{23}$ Por. ibidem, s. 47-48.
} 
takie, przestały w ogóle istnieć. W obozach przede wszystkim myślało się o umieraniu, a nie o śmierci. Ta ostatnia nie była w poważaniu, ponieważ bardziej od niej, wspomina Améry, więźniów interesowała konsystencja zupy niż dylematy takie jak „być albo nie być”:

Rzeczywistość obozowa bez trudu zatriumfowała nad śmiercią i nad całym kompleksem tak zwanych kwestii ostatecznych. [...] W obozie [...] widać było bardziej przekonująco niż tam, za drutami, że na nic się nie przyda ani byt, ani światło bycia. Tam można było być głodnym, być zmęczonym, być chorym. Ale powiedzieć, że się po prostu jest - jest pozbawione sensu. A samo bycie jako takie stało się pojęciem definitywnie pozbawionym punktów odniesienia, a przez to pustym ${ }^{24}$.

Chrześcijańską odpowiedzią na powojenny głos rozpaczy Améry’ego była idea teologii cierpienia Boga Kazoha Kitamoriego. Japoński teolog w pracy opublikowanej zaraz po wojnie, w akcie cierpienia dostrzega istotę Boga. „Tylko przez nasze własne cierpienie możemy poznać cierpienie Boga" ${ }^{25}$. Do istoty Boga nie należy wcale wszechmoc, lecz właśnie jego męka na krzyżu i tym samym współcierpienie z człowiekiem. Bóg nie jest odpowiedzialny za zło na ziemi, on prawdziwie cierpi jako Chrystus wtedy, gdy wydarza się każde zło.

Wyjście z sytuacji, w której bycie sprowadza się tylko do jednej z opcji czyli nie-bycia, śmierci, wskazuje - o czym Tillich jest przekonany - wiara mająca charakter osobistego spotkania, naznaczona ufnością, która pokonuje śmierć, lęk, grzech i zło. Ufność stanowi istotę i substancję męstwa. Nie jest to męstwo bycia jako część, w znaczeniu przynależności do pewnej grupy czy wspólnoty, ponieważ w tej relacji występują tylko dwie osoby: jednostka i Bóg, a spoiwem je łączącym jest męstwo ufności. Nie ma pośredników ani w postaci Kościoła, ani w postaci społeczeństwa czy państwa. Męstwo to nie jest również męstwem bycia sobą, ponieważ nie pokłada ufności w sobie, ani męstwem bycia jako część, gdyż nie ukształtowało się w jakiejś szczególnej grupie społecznej lub etnicznej, nie opiera się również na czymś, co ma wymiar skończony, lecz na Bogu' ${ }^{26}$.

Tillich sądzi, że paradoksalność religijnej wiary ujawnia się w tym, że mimo istnienia ontycznej przepaści między transcendentnym Bogiem a człowiekiem, można ją zniwelować w doświadczeniu wiary. To głosiła już expressis verbis reformacyjna zasada sola fide, stanowiąca jedno z pryncypiów teologii ewangelickiej ${ }^{27}$. Teoretycznie wiara potwierdza coś, co nie ma statusu pewności, jest przyjęciem tego, co wykracza poza doświadczenie. Wiara to stan dający możliwość akceptacji siebie z racji wiedzy, że jest się akceptowanym przez Boga ${ }^{28}$.

${ }^{24}$ Ibidem, s. 57-58.

${ }^{25}$ Wyd. angielskie: K. Kitamori, Theology of the Pain of God, Richmond, VA 1965, s. 41 (thum. własne).

${ }^{26}$ Por. P. Tillich, Męstwo bycia, op. cit., s. 170-176 oraz idem, Teologia systematyczna, t. 1, thum. J. Marzęcki, Kęty 2004, s. 163-166.

27 J. Sojka, Główne idee teologiczne wittenberskiej Reformacji, „Rocznik Elbląski” 2018, t. XXVIII, s. 56 .

${ }^{28}$ P. Tillich, Męstwo bycia, op. cit., s. 185. 
Zdaniem Tillicha tylko cnota męstwa może pokonać lęk przed brakiem sensu i wątpieniem. Człowiek świadomy swej skończoności powinien zaakceptować bezsens istnienia właśnie jako pozbawiony sensu i rozpaczliwy ${ }^{29}$. Akt ten sam w sobie jest sensowny, ponieważ na jego mocy wierzy się, że sens bycia istnieje, chociaż się go nie doświadcza. Ten akt akceptacji bezsensu jest sam w sobie sensowny i afirmatywny ${ }^{30}$, przez co odsyła do rzeczywistości, która wykracza poza ludzkie rozumienie świata. Dla tej sfery fundamentem istnienia jest Bóg, Moc Boża. To z niej człowiek czerpie swe osobiste męstwo do bycia, do podjęcia wyboru afirmującego byt. W tej perspektywie wiara stanowi „troskę ostateczną” jednostki ludzkiej ${ }^{31}$. Najpełniejszy jej wyraz człowiek odnajduje w Bogu. Człowiek jest tym, który oczekuje na przyjście Boga.

W myśleniu Tillicha na temat objawienia można zauważyć dwa elementy konstytuujące. Po pierwsze ekstazę, która rozumiana jest jako wyjście z siebie, umożliwiające pełniejszy powrót do siebie. Po drugie cud, stanowiący rzeczywistość odsłonięcia ${ }^{32}$. Dla pełnego dokonania się objawienia konieczne jest odsłonięcie się Boga przed człowiekiem i zarazem otwarcie człowieka na Boga. Jednakże to Bóg ostatecznie otwiera podmiot na siebie, dlatego ekstazę poprzedza oczekiwanie na cud, przyjście Boga. W tym oczekiwaniu zawarty jest pewien element przygotowania się na przyjęcie Boga w postaci ufnego i niecierpliwego wyglądania, jak również gotowości na to, co nadchodzi.

Ekstatyczny charakter wiary wykracza poza racjonalną świadomość oraz irracjonalną nieświadomość, przy jednoczesnym zachowaniu własnej tożsamości i wszystkich innych elementów, które jednoczą się w centrum osoby ${ }^{33}$. Ekstatyczny charakter wiary nie wyklucza jej racjonalnego rysu. W każdym jej akcie występuje ,poznawcza afirmacja", będąca efektem całkowitej akceptacji i poddania się. Nie jest ona jednak wytworem woli ${ }^{34}$ ani wulkanem emocji. Wiara jest czynnikiem integrującym i wiążącym, łączy elementy skupionej w sobie jaźni i angażuje ją za sprawą aktu „absolutnej, nieskończonej i ostatecznej troski” ${ }^{35}$. Dlatego stanowi „tkwiącą w człowieku możliwość" "36, dążącą do urzeczywistnienia. Ku wierze jednostkę pociągają obecna w niej świadomość i pragnienie nieskończoności.

Jak zauważa Tillich, istnieje również wiara bałwochwalcza, w której nie można przezwyciężyć dualizmu podmiot-przedmiot. W wierze tej do rangi rzeczy ostatecznych podnosi się to, co skończone, na przykład państwo, rasę, sukces czy rozum. Przedmiot naszej wiary może zniszczyć człowieka, jak również go uleczyć, nigdy jednak nie można się go pozbyćc ${ }^{37}$. Jako że wiara jest czymś ryzykownym ${ }^{38}$, prawdziwym

\footnotetext{
29 Por. ibidem, s. 188.

30 Por. ibidem, s. 189-190.

31 P. Tillich, Dynamika wiary, tłum. A. Szostkiewicz, wstęp J.A. Kłoczowski, Poznań 1987, s. 31.

32 P. Tillich, Teologia systematyczna, t. 1, s. 108-113.

33 P. Tillich, Dynamika wiary, op. cit., s. 35.

34 Ibidem, s. 36.

35 Ibidem.

36 Ibidem, s. 37.

37 Ibidem, s. 39-42.

38 Ibidem, s. 44.
} 
męstwem jest podjąć ryzyko porażki wpisanej w egzystencję. W sposób szczególny zagrożenie fiaskiem jest wpisane w samo chrześcijaństwo. To, co w oczach świata uchodzi za sukces, z punktu widzenia chrześcijaństwa i wieczności jest niczym, jest śmiercią wobec Boga. Paradoks ten jest wynikiem dwuaspektowości egzystencji ludzkiej, o której pisał już Kierkegaard. Śmierć, „przeglądając się” w wieczności, jest życiem (dla Boga), choć w codzienności, w światowości, nadal oznacza siebie samą, kres wszystkiego, co niesie ze sobą życie. Z kolei życie, które przegląda się w wieczności, jest śmiercią (względem świata), choć i ono tu, w codzienności, zachowuje swój pierwotny sens ${ }^{39}$. Kierkegaard, posługując się paradoksem, odsyła do świata ukrytego dla oka człowieka, którego nie da się opisać językiem naturalnym. Podobnie myśli o paradoksie Tillich, jest on dla niego tym, co stoi w sprzeczności $\mathrm{z}$ doxa, ,opinią zasadzającą się na całym normalnym ludzkim doświadczeniu. [...] Chrześcijański paradoks zaprzecza opinii wywiedzionej z ludzkiego, egzystencjalnego predykamentu i z wszelkich wyobrażalnych na podstawie tego predykamentu oczekiwań" ${ }^{40}$. Jeśli nawet życie nie posiada sensu w oczach pragmatycznie zorientowanego świata, to z punktu widzenia chrześcijańskiego żadne ludzkie życie nie jest go pozbawione. Wiara w Moc Bytu „gwarantuje” jedynie zachowanie nadziei na nieoczywisty (ukryty) sens egzystencji, mimo jawnego braku owego sensu w codzienności życia. Jednakże każda inna treść wiary jako troski ostatecznej wykaże swą tymczasowość, niewystarczalność, demoniczność i bałwochwalczy charakter, a życie ujawni jako nieprawdę.

Wiara jako problemem egzystencjalny jest ludzkim „być albo nie być”. Nie da się usunąć z człowieka ani wiary, ani wątpliwości. U ludzi świętych wątpienie przybiera postać pokus, u ludzi z tak zwaną ,niezachwianą wiarą” przejawia się w faryzeizmie i fanatyzmie. Zdaniem autora Teologii systematycznej wątpienie pokonać można męstwem, które dopuszcza do siebie wątpliwości jako wyraz skończoności i ograniczoności ludzkiej egzystencji. Męstwu zbędna okazuje się pewność, ponieważ obejmuje i akceptuje ono ryzyko związane z podjęciem wysiłku wiary. Samo twórcze życie nie istnieje bez ryzyka.

Można przypuszczać, że ci z ludzi, którzy żyją zauroczeni estetyczną stroną by$\mathrm{cia}^{41}$, nie odczuwają niepokoju, nie miewają rozterek aż do chwili, w której „ziemia zaczyna im trzeszczeć pod stopami”², egzystencję spowija nieoczywistość, a uwaga skupia się na głębi własnej duszy. Odkrycie tej głębi spowodować może pojawienie się lawiny pytań o sens życia oraz załamanie dotychczasowego beztroskiego

39 Por. S. Kierkegaard, Zalecone dla własnej oceny wspótczesności, [w:] idem, Pisma późne, tłum. i komentarze K. Toeplitz, wstęp M. Urbańska-Bożek, Kęty 2016, s. 219.

40 P. Tillich, Teologia systematyczna, t. 2, s. 90.

41 Używając wyrażenia ,estetyczna strona bycia”, odnosimy się wprost do „estetycznego stadium życia” opisanego przez Kierkegaarda, które charakteryzuje się tym, że człowiek przede wszystkim skupia się na doświadczaniu przyjemności i rozkoszy w różnych jej rodzajach i odcieniach. Stadium etyczne, które następuje po estetycznym, cechuje postawa adaptacji, uwewnętrznienia, przyswojenia sobie obowiązku i norm etycznych. Zarówno etap estetyczny, jak i etyczny naznaczony mógł być cierpieniem, jednakże nie zawsze, ponieważ po pierwsze, było ono czymś przypadkowym i przejściowym, po drugie, można było je odrzucić. Z kolei religijne stadium życia jest już z cierpieniem nierozerwalnie związane.

42 Parafraza zdania z Notatek z podziemia Fiodora Dostojewskiego. 
i bezrefleksyjnego sposobu bycia. Stało się to udziałem Hamleta, bohatera tragedii Williama Szekspira, który dojrzał do odkrycia w sobie pełni człowieczeństwa, z donżuana stał się najpierw mścicielem, a w końcu filozofem. Bohater obudził w sobie coś, nad czym nie potrafił jeszcze zapanować. Do tej pory był aktorem, nie żył, lecz grał siebie, bawił się życiem, więc gdy przyszło mu żyć naprawdę, był całkowicie bierny, bezradny, pozbawiony wiary i mocy sprawczej ${ }^{43}$. Małgorzata Grzegorzewska w swej najnowszej książce na temat wątków teologicznych w tragediach Szekspira pisze:

[...] w tragedii Szekspirowskiej powodem, dla którego świat marniał, szarzał i rozpadał się na kawałki, było zgorzkniałe, wyzute z miłości spojrzenie bohatera. [...] każdy ruch księcia ulega unieważnieniu. Udaje on szaleńca, ale nie mówi jak szaleniec, kocha jak nie kochany, prorokuje jakby nie prorokowat ${ }^{44}$.

Tillich powiedziałby, że bierność Hamleta wypływa z jego braku wiary, z którą zintegrowane jest działanie. Zachodzi między nimi korelacja, mająca na celu stymulację jednego elementu przez drugi. Innym komponentem wiary, obok działania, jest miłość, którą teolog rozumie jako „pragnienie ponownego połączenia się z tym, do czego się należy" ${ }^{\prime 5}$. W tym przypadku do połączenia się ze swą „dynamiczna otchłanią" - Ungrund ${ }^{46}$, pierwotnym źródłem - Bogiem. W chwili dotknięcia pustki i bezsensu własnej egzystencji demon wątpienia budzi się nie tylko w Hamlecie, lecz w każdym innym człowieku znajdującym się w podobnej sytuacji. Ten demon bez przeciwwagi, jaką daje męstwo podjęcia ryzyka, czyli wiara, prowadzi na skraj przepaści.

Czytając historię krótkiego życia wyimaginowanego księcia Danii, odnosi się wrażenie, że czekał on na objawienie. Stąd wahanie i niezdecydowanie, sugerujące, iż wypatrywał znaku oraz odpowiedzi na mnożące się wątpliwości. Ostatecznie jednak zagadka bytu nie została przed nim odsłonięta (cud nie zaistniał). Dlaczego? Podążając za intuicją Tillicha, odpowiemy, że ze strony księcia nie doszło do otwarcia się na Boga. Hamletowi, być może, nie starczyło już czasu, aby przygotować się na cud i przyjęcie objawienia. Bóg pozostał zatem zakryty dla oczu jego duszy. Samo oczekiwanie to zbyt mało, by Ten, na którego się czeka, przybył; można by wówczas, niczym bohaterowie dramatu Samuela Becketta, pozostać na zawsze w stanie oczekiwania na przyjście Nieuwarunkowanego ${ }^{47}$. Mimo że Bóg ostatecznie otwiera człowieka na siebie, to jednak ten drugi nie może pozostać bierny.

${ }^{43}$ W.H. Auden, Wykłady o Shakespearze, tłum., wstęp i posłowie P. Nowak, Warszawa 2016, s. $207-215$.

${ }^{44}$ M. Grzegorzewska, Teologie Szekspira, Kraków 2018, s. 111.

${ }^{45}$ P. Tillich, Dynamika wiary, op. cit., s. 116.

46 John Thatamanil pisze, że odrzucenie przez Tillicha boskości w znaczeniu actus purus oznacza, iż jego Bóg jest bardzo podobny do Podstawy/Fundamentu (Grund) rozumianego jako Ungrund, pojęcia oznaczającego w swym najgłębszym rozumieniu dynamiczną otchłań. Por. J. Thatamanil, Tillich and the Postmodern, [w:] R.R. Manning (red.), The Cambridge Companion to Paul Tillich, Cambridge-New York 2010, s. 299.

${ }^{47}$ S. Beckett, Czekając na Godota, [w:] Dzieła dramatyczne, thum, wstęp i przypisy A. Libera, Warszawa 1988, s. 29-132. 
Na koniec odwołamy się raz jeszcze do Améry'ego oraz do Fiodora Dostojewskiego, chrześcijańskiego egzystencjalisty, wywodzącego się z tradycji wschodniej. Ten pierwszy, jako antyegzystencjalista nie dokonuje namysłu nad sensem istnienia, logiką życia czy też bycia, lecz nad jego bezsensem, swoistą antylogiką istnienia, którą akceptuje w pełni i broni przed, jak to określa, ludową mądrością: „Trzeba jakoś żyć"48. Staje tym samym po stronie tych, dla których „dobrowolna śmierć” (samobójstwo) jest śmiercią naturalną. Być może - przyznaje Améry - podobnie jak życie, śmierć dobrowolna jest absurdalna, nie jest jednak błazeńska, ,[...] bo przecież jej absurdalność nie powiększa absurdalności życia, lecz ją ogranicza"49. Nie mamy podstaw do tego, aby nie uznać, że istnieją ludzie egzystujący „w poczuciu wstrętu do bytu" ${ }^{50}$ oraz do życia. Odrzucenie argumentacji Améry'ego, że życie w świadomości tego, iż buduje się dom, aby ten zawalił się „,w święto zawieszenia wiechy”" jest czymś równie absurdalnym jak ucieczka przed śmiercią w śmierć, czyli „Z absurdu życia w absurd nicości" 52 .

W Biesach Dostojewskiego Wierchowieński mówi, że Szekspir i Rafael rozprawiają o sensie bycia, tego, dla czego żyć warto. Dla bohatera jedyną wartość stanowi piękno, którego ci dwaj są uosobieniem: ,[...] to osiągnięty już kształt piękna, bez którego kto wie, może nie zgodziłbym się żyć" ${ }^{33}$. Dostojewski oraz Améry wskazują na potrzebę „,nadania egzystencji gęstości” ${ }^{54}$. Tym „zagęszczaczem” może być zarówno miłość biednej służącej do „«dwojga baśniowych oczu pięknych niczym gwiazdy» i zniewalającego głosu, który cicho rozbrzmiewał w słuchawkach" ${ }^{55}$, bez których nie widzi ona sensu dalszego życia, jak i uwielbienie dla Szekspira oraz Rafaela. Bez nich życie stałoby się pozbawione dalszego sensu już na zawsze i nieodwracalnie. Niemniej, czy to, co skończone, może stanowić przedmiot „troski ostatecznej" oraz wypełnić pustkę wyzierającą z ludzkiej duszy?

W sytuacji granicznej oparcie się człowieka na tym, co skończone, na przykład na rozumie, prowadzi, jak wskazuje przypadek Jeana Améry'ego, do zapaści dotychczasowej hierarchii wartości, do załamania się wiary, która dawała siłę do życia i nadawała mu sens. Rozum jako skończony, dotarłszy do własnych granic, nie może stanowić źródła dla męstwa bycia, w przeciwieństwie do wiary w Moc Boga. W Nim przejawia się miłość, której zarazem urzeczywistnieniem i najpełniejszym objawieniem jest Jezus Chrystus. Miłość Boga-Chrystusa otwiera na przebaczenie. W warunkach obozów śmierci tak zwane „prawdy obiektywne”, ,prawdy naukowego poznania" straciły racje swojego istnienia. W tych warunkach jedyną nadzieją mogła stać się siła o wiele potężniejsza od rozumu, a mianowicie paradoks wiary, największy

48 J. Améry, Podnieść na siebie rękę. Dyskurs o dobrowolnej śmierci, thum. i przedmowa B. Baran, Warszawa 2018, s. 87.

49 Ibidem, s. 177.

${ }^{50}$ Ibidem, s. 73.

${ }^{51}$ Ibidem, s. 66.

52 Ibidem, s. 72.

${ }_{53}$ F. Dostojewski, Biesy, tłum. T. Zagórski, Z. Podgórzec, [w:] Dzieła wybrane, t. 3, Warszawa 1984, s. 438-484.

${ }^{54}$ J. Améry, Podnieść na siebie rękę, op. cit., s. 37.

${ }^{55}$ Ibidem. 
z możliwych - jak twierdził Kierkegaard, a za nim Tillich - Bóg-Człowiek. Według filozofa z Kopenhagi tam, gdzie rozum i logika, a także świadectwa zmysłów zawodziły, w rolę instancji rozstrzygających wcielały się wola oraz wolność. Pewności wiary nie można uzasadnić za pośrednictwem poznania. Ona „dawała się jedynie usprawiedliwić jako «wola wierzenia», jako efekt subiektywnej namiętności, wyboru, wolności" - pisał Edward Kasperski ${ }^{56}$.

Istnieje niebezpieczeństwo, że piękno światowe, prawda naukowa, wolność i inne kategorie zdefiniowane przez rozum ludzki staną się demoniczne i nihilistyczne w oderwaniu od Stwórcy oraz boskiego porządku. Améry, podobnie jak fikcyjny książę Danii czy Wierchowieński, własną wiarę ulokował poza Bogiem-Miłością. Odpowiedzią Tillicha dla tych, którzy płoną „w ogniu gniewu własnego wiecznie, łaknąc śmierci i niebytu"57, którzy przeżywają egzystencjalne piekło, jest zwrot ku Mocy Boga, z której mogliby czerpać męstwo dla własnego bycia. Człowiek opierający się jedynie na mocy rozumu w chwili załamania się dotychczasowych systemów wartości ustanowionych przez sam intelekt, w czasie kryzysu, nie mogąc nadal czerpać siły do bycia z dotychczasowego źródła, woli z życia zrezygnować. W tej perspektywie życie nabiera negatywnego charakteru, ,wypełnia się” pustką - brakiem miłości. Jako takie jest piekłem doczesności. Akceptacja obecności tego piekła niszczy wewnętrzną sferę jaźni. Utrata męstwa wiąże się wprost z brakiem nadziei, wiary i miłości. Z kolei otwarcie się na Boga-Miłość „,dokonuje w człowieku realnej przemiany, uzdrawia istniejące w nim infernalne przestrzenie i czyni ludzkie istnienie pełnym i pięknym"58.

\section{Podsumowanie}

Analiza egzystencjalna nie tylko ujawnia obcość jednostki względem siebie samej oraz niewiedzę na temat własnego bytu, lecz również prowadzi do ujawnienia jaźni głębokiej, czyli duszy, do odkrycia przez jednostkę siebie samej, co powoduje, że zaczyna ona żyć własnym życiem, pragnie powrócić do siebie i swej jaźni. Dlatego jednostka sięga do pytań, które stanowią udrękę jej życia. Pytania te nie znajdują odpowiedzi, a mimo to od nowa są stawiane: o sens bytu i bycia, tak własnego, jak i świata ${ }^{59}$. Okazuje się, że to człowiek jest sam w sobie zagadką i pytaniem o istotę swojej wiary oraz jej sens. Odpowiedź odnajduje we własnym wnętrzu, zaś potrzeba odniesienia siebie do sfery sacrum jest warunkiem koniecznym dla urzeczywistnienia siebie w pełni swego człowieczeństwa. Jednostka ludzka, o czym przekonany był już Kierkegaard, a w ślad za nim Paul Tillich, żyje w permanentnym napięciu między skończonością a nieskończonością, wolnością/możliwością a koniecznością. Dla

${ }^{56}$ E. Kasperski, Kierkegaard. Antropologia i dyskurs o człowieku. Monografia, Pułtusk 2003, s. 404.

${ }^{57}$ F. Dostojewski, Biesy, op. cit., s. 383.

${ }^{58}$ E. Mikiciuk, Teatr paschalny Fiodora Dostojewskiego. O watkach misteryjnych Braci Karamazow $i$ ich wizjach scenicznych, Gdańsk 2009, s. 208.

${ }_{59}$ P. Tillich, Pytanie o Nieuwarunkowane. Pisma z filozofii religii, thum. J. Zychowicz, przedmowa K. Mech, Kraków 1994, s. 81-83. 
osiągnięcia równowagi duchowej, scalającej osobowość, konieczne jest, aby jednostka zwróciła się ku własnemu centrum osobowemu oraz Bogu, jako tej mocy, z której czerpie i w której uczestniczy męstwo bycia pojedynczej istoty. Daje to możliwość wyjścia z rozpaczy. Tym, co zdaniem obu teologów stoi w kontrapunkcie wobec niej, jest wiara. Dla Kierkegaarda ta ostatnia stanowi uzgadniające się spotkanie z cierpieniem $^{60}$, dla Tillicha jest najwyższym wyrazem „troski ostatecznej”. A zatem alternatywa wykluczająca - być albo nie być - zostaje zniesiona za sprawą wiary, która podobnie jak życie jest ryzykiem, jakie każdy indywidualnie musi podjąć. Swoją najbardziej fundamentalną pracę poświęconą wprost tematowi wiary Tillich kończy konkluzją o możliwości i potrzebie wiary w chwili obecnej ${ }^{61}$. Teolog stwierdza, że współczesne (tj. dwudziestowieczne) odrzucenie wiary wynika z niezrozumienia jej istoty. Prawdziwe zwycięstwo wiary ma miejsce tam, gdzie jednostka samodzielnie rozpoznaje, że poza troską przedostateczną, czyli doczesnością, odkrywa się głębię bytu, troszczy się o to, co ostateczne. By podjąć ten trud, trzeba mieć odwagę i wykazać się męstwem. W teologii fillozoficznej Tillicha męstwo bycia, rodzące się z wiary, jest od-słowem zarazem dla bezsensu życia, rozpaczy, jak i ,śmierci dobrowolnej”. Tillichowska próba powrotu do logiki życia, afirmacji istnienia i stawienia czoła klęsce oraz niepowodzeniu, a także byciu, mimo ewidentnie tkwiącego w nim bezsensu, jest świadomym podjęciem ryzyka wkalkulowanego w życie i wynika z wiary, że wbrew temu wszystkiemu można żyć, co nie oznacza, że życie przestaje być zarazem pytaniem i ,tragedią dla tych, którzy myślą"62.

\section{Bibliografia}

Abromeit H.-J., The Luther Effect: What Was the Aim of the Reformer and What Was the Result?, „Gdański Rocznik Ewangelicki” 2017, vol. 11, s. 107-114.

Améry J., Podnieść na siebie rękę. Dyskurs o dobrowolnej śmierci, thum. i przedm. B. Baran, Warszawa 2018.

Améry J., Poza wina i karą. Próby przełamania podjęte przez złamanego, tłum. R. Turczyn, posł. opatrzył P. Weiser, Kraków 2007.

Auden W.H., Wykłady o Shakespearze, tłum., wstęp i posłowie P. Nowak, Warszawa 2016.

Beckett S., Czekając na Godota, [w:] Dzieła dramatyczne, tłum., wstęp i przypisy A. Libera, Warszawa 1988.

Bergson H., Ewolucja twórcza, thum. F. Znaniecki, wstęp L. Kołakowski, Kraków 2004.

Dostojewski F., Biesy, tłum. T. Zagórski, Z. Podgórzec, [w:] Dzieła wybrane, t. 3, Warszawa 1984.

Dostojewski F., Bracia Karamazow, thum. A. Wat, [w:] Dzieła wybrane, t. 3, Warszawa 1984.

Dostojewski F., Notatki z podziemia. Gracz, tłum. G. Karski, [w:] Z dziet Fiodora Dostojewskiego, t. 1, Londyn 1992.

Grzegorzewska M., Teologie Szekspira, Kraków 2018.

Heidegger M., Bycie i czas, thum. B. Baran, Warszawa 2010.

${ }^{60}$ S. Kierkegaard, Choroba na śmierć, [w:] idem, Bojaźń i drżenie. Choroba na śmierć, tłum. i wstęp J. Iwaszkiewicz, Warszawa 1969, s. 224.

61 P. Tillich, Dynamika wiary, op. cit., s. 127.

${ }^{6}$ S. Stomma, Oczyma świadka, [w:] J. Skoczyński, Wartość pesymizmu. Studia i szkice o Marianie Zdziechowskim, Kraków 1994, s. 11. 
Jaeger W., Paideia, t. 1, thum. M. Plezia, Warszawa 1962.

Kasperski E., Kierkegaard. Antropologia i dyskurs o człowieku. Monografia, Pułtusk 2003.

Kierkegaard S., Albo-Albo, thum. K. Toeplitz, tłum. wierszy J. Iwaszkiewicz, t. 2, Warszawa 2010.

Kierkegaard S., Bojaźń i drżenie, tłum. K. Toeplitz, wstęp J.A. Prokopski, red. nauk. M. Urbańska-Bożek, Kęty 2018.

Kierkegaard S., Choroba na śmierć, [w:] tenże, Bojaźń i drżenie. Choroba na śmierć, thum. i wstęp J. Iwaszkiewicz, Warszawa 1969, s. 141-291.

Kierkegaard S., Zalecone dla własnej oceny współczesności, [w:] S. Kierkegaard, Pisma późne, tłum. i komentarze K. Toeplitz, wstęp M. Urbańska-Bożek, Kęty 2016, s. 147-227.

Kitamori K., Theology of the Pain of God, Richmond, VA 1965.

Łata J., Odpowiadająca teologia Paula Tillicha, Oleśnica 1995.

Mikiciuk E., Teatr paschalny Fiodora Dostojewskiego. O watkach misteryjnych „Braci Karamazow" i ich wizjach scenicznych, Gdańsk 2009.

Milerski B., Religia a Słowo. Krytyka religii w ujęciu Dietricha Bonhoeffera i Paula Tillicha, Łódź 1994.

Napadło M., Pytanie o Boga... Filozofia religii Paula Tillicha, Płock 2015.

Parandowski J., Człowiek homerycki, „Roczniki Filozoficzne” 1949/1950, t. 2/3, s. 199-204.

Shakespeare W., Hamlet, tłum. S. Barańczak, Kraków 1997.

Sojka J., Główne idee teologiczne wittenberskiej Reformacji, „Rocznik Elbląski” 2018, t. XXVIII, s. 53-65.

Stomma S., Oczyma świadka, [w:] J. Skoczyński, Wartość pesymizmu. Studia i szkice o Marianie Zdziechowskim, Kraków 1994.

Thatamanil J., Tillich and the Postmodern, [w:] R.R. Manning (ed.), The Cambridge Companion to Paul Tillich, Cambridge-New York 2009, s. 288-302.

Theißen H., Der gemeinsame reformatorische Grund des Glaubens, „Gdański Rocznik Ewangelicki” 2013, vol. 7, s. 308-321.

Tillich P., Teologia systematyczna, t. 1-3, tłum. J. Marzęcki, Kęty 2004-2005.

Tillich P., Dynamika wiary, tłum. A. Szostkiewicz, wstęp J.A. Kłoczowski, Poznań 1987.

Tillich P., Męstwo bycia, tłum. H. Bednarek, Poznań 1994.

Tillich P., Pytanie o Nieuwarunkowane. Pisma z filozofii religii, tłum. J. Zychowicz, przedmowa K. Mech, Kraków 1994.

Weiser P., Dramat ocalenia Jeana Améry'ego, [w:] J. Améry, Poza wina i kara. Próby przełamania podjęte przez złamanego, thum. R. Turczyn, posł. opatrzył P. Weiser, Kraków 2007, s. 225-244. 
